\title{
RECENT DEVELOPMENTS IN THE FEDERALPROVINCLAL DISPUTE CONCERNING JURISDICTION OVER OFFSHORE PETROLEUM RESOURCES
}

\author{
IAN TOWNSEND GAULT*
}

\begin{abstract}
Great uncertainty surrounds the question of jurisdiction over natural resources in the offshore regions in Canada and this problem has become acute in recent years with the discovery of petroleum off the Canadian East coast. The author explains the roots and reaches of the dispute in light of both Canadian and American jurisprudence. The positions of the Federal government and the provinces of Nova Scotia and Newfoundland are explored together with the current working agreements these governments have reached on the political level. Finally, recent cases are analyzed and the author outlines what future developments to look for in the area.
\end{abstract}

\section{INTRODUCTION}

Exploration of the Canadian continental shelf has been going on since 1960, when Mobil Oil was granted an exploration licence off the coast of Nova Scotia. ${ }^{1}$ The petroleum licensing regime for the Canada Lands (an area which was, in effect, deemed to include the shelf) was re-drafted that year following consultations with the industry. ${ }^{2}$ The new regime was designed to provide powerful incentives for undertaking exploration of frontier areas.

These regulations were substantially amended in $1977^{3}$ and then replaced in March, 1982, by the regime promulgated by the Canada Oil and Gas Act. ${ }^{4}$ This measure, like the 1977 regulations, sees Petro-Canada as a major actor in frontier development, and is also designed to encourage offshore exploration by oil companies, which allows equity participation by Canadians to a substantial degree.

Some twenty-eight countries are currently producing petroleum from the continental shelf. Canada, with an extensive and viable petroleum industry and one of the largest offshore areas pertaining to any coastal state, is not yet of their number. Extensive deposits of oil and natural gas have been found offshore; promising finds in the Arctic are also reported. Assuming, for the purposes of this paper, that there is the political and industrial will to exploit the hydrocarbon resources of the offshore, one must seek to explain why Canada has not completed the transitional stage from exploration to production. The United Kingdom and Norway, for example, have built up viable offshore petroleum industries from almost nothing in seventeen years. The two states have also evolved sophisticated regimes for regulating offshore pipeline construction and operation, transportation of oil by tanker, environmental protection (including opera-

* Research Associate, Canadian Institute of Resources Law, The University of Calgary.

1. The history of the early years of east coast exploration, as well as an outline of the technical and constitutional position are to be found in Gibbons and Voyer, "A Technology Assessment: A Case Study of East Coast Offshore Petroleum Exploration", Science Council of Canada, Background Study No. 30.

2. Canada Oil and Gas Land Regulations, SOR/60-182.

3. Canada Oil and Gas Land Regulations, SOR/77-666.

4. Canada Oil and Gas Act, S.C. $1980-81-82$, c. 81. 
tional debris), the activity of supply vessels, fishing and navigation in the vicinity of installations, and safe practices and worker safety on offshore installations. $^{5}$

The continuing Federal-provincial dispute concerning jurisdiction over offshore mineral resources is not necessarily the sole cause of Canada's present position, but must be a major factor contributing to it. In addition, the way in which the dispute has been handled by the protagonists, its longevity, and role in the Federal-provincial political process raise important questions of public policy.

This conclusion emerges with stark clarity when one surveys the remainder of the juridical framework within which offshore development currently takes place. For example, it is nothing short of incredible that Canada has not made legislative provisions for the general application of civil and criminal law on offshore facilities, or for extending the jurisdiction of the courts. These questions are dealt with elsewhere in this volume in papers by Professor de Mestral and Professor Mendes. ${ }^{6}$ Canada has not promulgated a safety code for these installations comparable to those applicable in the United Kingdom or Norway, which recognize the particular requirements of offshore operations. ${ }^{7}$

The point is, the word "jurisdiction" has been all too narrowly defined in Canada. The protagonists in the offshore resources dispute, while concerned with safeguarding their rights, have perhaps neglected areas of traditional government responsibility, and the failure to provide adequate regulation of safety on installations on the Canadian continental shelf is only one example. However, as will be discussed later in this paper, a recent decision of the Federal Court, The Seaman's International Union v. Crosby Offshore Services, ${ }^{8}$, serves as a reminder that the legal regime for oil and gas development on the Canadian continental margin, be it Federal or provincial, will not displace the existing constitutional framework which determines the respective spheres of Federal and provincial jurisdiction. It will be the task of lawyers, and possibly politicians also, to determine anew the extent and nature of these jurisdictional boundaries in light of the decisions of the Supreme Court of Canada in cases dealing with offshore jurisdiction currently before it (i.e., the Strait of Georgia and Newfoundland offshore cases). The following notes are intended to summarize the constitutional position as these matters come before the Supreme Court of Canada. It now appears that a political settlement of these issues is unlikely until the two decisions are handed down.

5. This is not to deny, however, that there are some serious deficiencies in the respective legal regimes for the offshore. A recent penetrating study of the safety position on British offshore oil installations highlights what is, perhaps, the most serious problem: see Carson, The Other Price of Britain's Oil (1982).

6. See Professor de Mestral at 63 and Professor Mendes at 1.

7. It is certainly true that, in this case at least, some lessons from the North Sea have not been heeded by Canadian authorities. The U.S. inquiry into the loss of the Ocean Ranger disclosed that it was not clear where the ultimate authority lay on board the installation at any one time, yet the British inquiry into the loss of the oil rig Sea Gem in 1965 was at pains to point out a failure to designate ultimate authority in this way was inherently dangerous, and the omission was subsequently rectified by legislation.

8. The Seaman's International Union v. Crosbie Offshore Services (1982) 135 D.L.R. (3d) 485 (F.C.A.). 


\section{BACKGROUND TO THE DISPUTE}

The nature and extent of the coastal state's rights in marine and submarine areas beyond the limits of the territorial sea are determined by international law, but must be implemented by domestic law. Domestic jurisdiction includes not only exploration for and exploitation of submarine mineral resources, but also a whole range of concommitant enterprises. Thus, the Convention on the Continental Shelf ${ }^{9}$ provides that coastal states exercise sovereign rights over the shelf for the purpose of exploration and exploitation of the mineral resources thereof, and the right to construct, maintain, and exercise jurisdiction over installations and other facilities. ${ }^{10}$

The extent to and manner in which these rights are exercised are determined through the domestic law and policy making processes subject to relevant international obligations. Federal systems must also determine which level of government is to exercise these rights and discharge the associated responsibilities - a process unitary states escape.

This problem, insofar as it pertains to jurisdiction over the resources, has arisen and largely been disposed of in the United States. The Australians have recently implemented a Federal-state joint jurisdiction arrangement, ${ }^{11}$ previously, jurisdiction had vested in the Federal government alone. ${ }^{12}$

The Federal-provincial dispute concerning jurisdiction over offshore mineral resources has been going on for almost two decades. While Australia and the United States appear to have settled the problem as it arose in their respective constitutional settings, a number of legal and political landmarks have come and gone in Canada which might reasonably have been expected to have provided total or partial solutions to the dispute.

The 1967 decision of the Supreme Court of Canada in the Reference re Offshore Mineral Rights of British Columbia ${ }^{13}$ in favor of the Federal government seemed to give Ottawa a strong hand in the argument. Almost a decade later, the Maritime provinces concluded a revenue sharing and joint jurisdiction agreement with the Federal government, an agreement which, however, was never implemented.$^{14}$ Newfoundland abandoned this particular exercise early on and promulgated a provincial petroleum licensing act and regulations and commenced issuing permits in areas already licensed, or which were subsequently licensed, by the Federal government. Hence there is a rather curious spectacle of some East Coast licensees holding duplicate exploration permits from both the Federal and provincial governments, pending a resolution of the dispute.

9. Convention on the Continental Shelf, Geneva, April 29, 1958; see S.H. Lay, 1 New Directions in the Law of the Sea (1973) 101.

10. Id., Article 5 .

11. See Offshore Constitutional Settlement - A Milestone in Cooperative Federalism, Australian Government Publishing Service (1980). Legislation implementing the new system is waiting proclamation.

12. Petroleum (Submerged Lands) Act 1967, Statute of Australia 1967, no. 118; see also New South Wales v. Commonwealth (1976) 135 C.L.R. 337.

13. [1967] S.C.R. 792.

14. Federal-Provincial Memorandum of Understanding in Respect of the Administration and Management of Mineral Resources Offshore of the Maritime Provinces, February 1, 1977. See Harrison, "The Offshore Mineral Resources Agreement in the Maritime Provinces"(1977-78) 4 DaL L.J. 245. 
Resolution of the dispute once and for all appeared to be at hand when the Progressive Conservative government of Prime Minister Clark announced its intention of recognizing exclusive provincial jurisdiction over petroleum resources of the continental shelf, a promise promptly repudiated by the succeeding Liberal government before implementation. The last two years have seen a renewal of negotiations between Ottawa on one hand and Newfoundland and Nova Scotia on the other. The Nova Scotia issue apparently has been settled by agreement ${ }^{15}$; the Newfoundland dispute is at present destined for determination by the Newfoundland Court of Appeal and subsequently by the Supreme Court of Canada. ${ }^{16}$ The Supreme Court will also hear an appeal by the Federal government from the decision of the British Columbia Court of Appeal in the Strait of Georgia Reference. ${ }^{17}$

Throughout this time, the oil industry on the Newfoundland shelf has been coping with the situation by taking out duplicate permits from Federal and provincial authorities, while making it clear that a speedy solution to the jurisdictional dispute is a sine qua non for offshore production. It is perhaps remarkable that the industry has consented to work in this climate of legal uncertainty, and more remarkable still that such pressures to resolve the dispute have only partially borne fruit.

\section{THE UNITED STATES' EXPERIENCE}

It was perhaps not surprising that the United States should provide the venue for the first intra-federal offshore jurisdictional dispute. That country had, after all, laid the foundations for the doctrine of the continental shelf in international law through the Truman Proclamation of 1945. ${ }^{18}$ The Proclamation was really a declaration of intent to the effect that the United States would henceforward regard the mineral resources of the continental shelf as appertaining to it, subject to its jurisdiction and control. This claim was justified on the grounds that the continental shelf, as the natural prolongation of the landmass, was physically one with the landmass; since these resources existed, and were certain to be exploited, it was merely prudent for the adjacent coastal state to assume jurisdiction to ensure orderly development of deposits. ${ }^{19}$

This claim was received enthusiastically by a number of states. As Sir Hersch Lauterpacht remarked in the Yearbook of International Law of 1950 ,

Seldom has an apparent major change in international law been accomplished by peaceful means more rapidly and amidst more general acquiesence and approval than in the case of the claims to

15. Canada-Nova Scotia Agreement on Offshore Oil and Gas Resource Management and Revenue Sharing, March 2, 1982.

16. The Lieutenant Governor of Newfoundland referred the question of offshore mineral jurisdiction to the Court of Appeal of the Supreme Court of Newfoundland on February 12th, 1982; the federal government referred the question over a part of the continental shelf which includes part of the Hibernia oil field to the Supreme Court of Canada on May 19th, 1982.

17. (1976) 1 B.C.L.R. 97 (C.A.).

18. Department of State Bulletin No. 327, September 30, 1945, p. 485.

19. Id. 
submarine areas - the seabed and its subsoil - adjacent to the coast of littoral states. ${ }^{20}$

On the other hand, Professor Kunz, writing in 1956, ${ }^{21}$ saw in the prolific variety of claims to offshore jurisdiction (which included designations of 200 nautical mile territorial seas by some Central and South American countries, and annexations of adjacent areas of seabed by the United Kingdom on behalf of some of her colonies) a threat to the established principle of the freedom of the seas rather than an emerging rule of international law with respect to submarine mineral resources alone.

The Truman Proclamation was accomplished by a Department of State press release $\mathrm{e}^{22}$ which attempted to underline the essentially international character of the presidential statement: it was not necessarily a claim on behalf of the Federal government over the resources but merely by the United States as a subject of international law.

The issue of state's rights in the offshore came before the Supreme Court of the United States three times in the five years following the Proclamation. The question at the root of all three cases (California ${ }^{23}$, Louisiana $^{24}$, and Texas ${ }^{25}$ ), was whether jurisdiction beyond the low water mark was vested in Federal or state authorities. The Supreme Court ruled that whatever circumstances had obtained prior to joining the Union, any rights exercisable beyond the low water mark now vested in the Federal government for purposes such as national defence. These decisions were sustained in a much later case, U.S. v. Maine $e^{26}$, a case which explicitly extended the ratio of the other decisions to the states along the Eastern Seaboard. This latest decision was handed down against a background of renewed Federal-state conflict regarding jurisdiction on the outer continental shelf. These cases did not specifically rule that the Federal government had jurisdiction over the resources of the continental shelf, but merely that the individual states did not.

Congress unilaterally claimed Federal jurisdiction over the continental shelf beyond the Territorial Sea - the "Outer Continental Shelf" ${ }^{27}$ and invested the coastal states with jurisdiction in the marginal sea adjacent to their coasts. ${ }^{28}$ The issue, therefore, appears to be settled juridically, if not politically, for the time being.

\section{CANADA - THE OFFSHORE MINERAL RIGHTS REFERENCE}

The dispute between the Federal government and British Columbia over jurisdiction in the offshore for exploration and exploitation of submarine natural resources came before the Supreme Court of Canada in

20. H. Lauterpacht, "Sovereignty Over Submarine Areas" (1950) 27 Brit. Y. Int. L. 376. The author cites and discusses the then existing claims. Modern claims are cited in the U.S. Department of State, Bureau of Intelligence and Research, issued by the Geographer, National Claims to Maritime Jurisdictions (Limits to the Sea - No. 36) (4th rev. 1981).

21. Kunz, "Continental Shelf and International Law: Confusion and Abuse" (1956) 50 Am.J. of Int. L. 828 .

22. Supra n. 18.

23. U.S. v. California 33 U.S. 19 (1947).

24. U.S. v. Louisiana 339 U.S. 266 (1950).

25. U.S. v. Texas 339 U.S. 707 (1950).

26. U.S. v. Maine 420 U.S. 515 (1975).

27. Outer Continental Shelf Lands Act, 43 U.S.C.S. $\oint$ 1331-1343.

28. Submerged Lands Act, 43 U.S.C.S. $\oint 1301$. 
$1967 .{ }^{29}$ The following questions were referred to the Court by the Governor-in-Council:

1. In respect of the lands, including the mineral and other natural resources, of the seabed and subsoil seaward from the ordinary low-water mark of the coast of the mainland and the several islands of British Columbia, outside the harbours, bays, estuaries and other similar inland waters, to the outer limit of the Territorial Sea of Canada, as defined in Chapter 22, as between Canada and British Columbia,

(a) Are the said lands the property of Canada or British Columbia?

(b) Has Canada or British Columbia the right to explore and exploit the said lands?

(c) Has Canada or British Columbia legislative jurisdiction in relation to the said lands?

2. In respect of the mineral and other natural resources of the seabed and subsoil beyond that part of the Territorial Sea of Canada referred to in Question 1, to a depth of 200 metres or, beyond that limit, to where the depth of the superjacent waters admits of the exploitation of mineral and other natural resources of the said areas, as between Canada and British Columbia,

(a) Has Canada or British Columbia the right to explore and exploit the said mineral and other natural resources?

(b) Has Canada or British Columbia legislative jurisdiction in relation to the said mineral and other natural resources?

The Court held unanimously that jurisdiction over these resources in the subsoil of the Territorial Sea and continental shelf rested absolutely and exclusively in the Federal government. It also ruled that the Federal government enjoyed proprietary rights over the Territorial Sea, its seabed and subsoil.

The questions referred to the Court were phrased in such a way that it was ultimately necessary to decide whether British Columbia enjoyed any of the disputed rights prior to her entry into Confederation in 1871. The Court canvassed the available historical material, and held that no such rights had been enjoyed, and such rights had not been vested in the province since that date. The issue was decided accordingly.

Not surprisingly, perhaps, the Court preferred to perceive the issue as one arising under Section 109 of the British North America Act (now the Constitution Act, of 1871), ${ }^{30}$ which guaranteed continuing provincial jurisdiction over minerals which appertained to the former colonies before entering Confederation. By choosing to approach the questions referred to it in this way, the Court raised and left unanswered some basic questions concerning the interrelationship between international law and Canadian constitutional law. Furthermore, questions arising out of section 132 and the Peace, Order and Good Government clause, section 91, were considered. ${ }^{31}$

The Court seems to have treated the questions arising from the case as if they could be assimilated to the jurisprudence relating to common law ownership of minerals. Put simply, this involves a search for evidence that provinces exercised such rights over offshore minerals before entering Confederation. While there is some evidence that offshore jurisdiction (of various kinds) was exercised, it was clearly deemed to be insufficient for

29. Reference Re Ownership of Off-Shore Mineral Rights (1967) 65 D.L.R. (2d) 353 (S.C.C.).

30. Constitution Act, 1867, 30-31 Vict., c. 3(U.K.).

31. Ivan L. Head, "Canadian Offshore Minerals Reference: The Application of Interna. tional Law to a Federal Constitution" (1968) 18 U. of T. L.J. 131. 
the present purposes..$^{32}$ This paucity of evidence is not surprising, because the precise nature of the states' rights seaward of the low water mark has been accorded the status of lex lata comparatively recently. The concept of the Territorial Sea is one of considerable antiquity, and is still plagued by a measure of uncertainty and disunity. A relatively straightforward matter such as the breadth of the Territorial Sea has not really been settledpresent day claims range anywhere from 3 to 200 nautical miles from the coast. ${ }^{33}$ As Dr. Marston has shown in his authoritative survey of law relating to the Territorial Seabed ${ }^{34}$ a variety of differing opinions has almost always been maintained and stoutly defended. It should be remembered that the famous case of The Franconia $a^{35}$ on which the Supreme Court of Canada, perhaps unwisely, chose to rely to a great extent - was decided by the very narrow majority of 7-6. The United Kingdom's own law and policy relating to offshore minerals was by no means a cohesive evolution, but rather a somewhat patchy series of responses to the exigencies of each particular situation. ${ }^{36}$ In these circumstances it is perhaps no cause for wonder that the Crown did not make an unambiguous grant of offshore jurisdiction to British Columbia while that entity was a British colony.

It was, of course, open to the Supreme Court of Canada to simply make a determination that British Columbia did not exercise jurisdiction over offshore resources. The Supreme Court of the United States had come to precisely this conclusion in the four cases referred to above. This left the way open for Congress to make a unilateral determination of rights over the resources of the inner and outer continental shelf between the states and the Federal government respectively. But the Supreme Court of Canada went further and held that rights over offshore resources vested in the Federal government by virtue of section 132 and section 91 of the B.N.A. Act and the accepted principles of international law, including the doctrine of the continental shelf. The Court specifically referred to Canada's treaty making power as a source of jurisdiction over a juridical concept which is entirely the creature of international law. ${ }^{37}$

This decision is not necessarily a comprehensive pronouncement, as the decision of the Court of Appeal of British Columbia in the Strait of Georgia Reference indicates. The Court in this case was asked to consider the following question: ${ }^{38}$

32. In the same connection it should be noted that Newfoundland and Nova Scotia also claim to have exercised some offshore jurisdiction before entering into Confederation, but, again, this may not satisfy the test of sufficiency which the Supreme Court of Canada appears to have carried out in this case.

33. Article 4 of the Draft Convention on the Law of the Sea would fix the breadth of the territorial sea at twelve nautical miles from the baselines. This limit is the maximum recognized as a matter of international customary law.

34. Marston, The Marginal Sea (1981).

35. R. v. Keyn (1876) L.R. 2, Ex. D. 63. Keyn was the master of the Franconia, a German ship, which collided with a British ship in U.K. territorial waters. Some thirty-nine persons on the British ship lost their lives. Keyn was charged with the manslaughter of some of the victims, and subsequently acquitted on the grounds that English criminal law did not apply to foreigners in the territorial sea in the absence of express statutory provisions. Marston, $i d$, discusses the case at some length at 114-151. The gap in the law was remedied by the Territorial Waters Jurisdictional Act of 1878 .

36. See, for example, Marston, supra n. 34, Part One.

37. Supran. 29.

38. Supran. 17. 
Are the lands or any part or parts thereof including the mineral and other natural resources of the seabed and subsoil, covered by the waters of the Strait of Juan de Fuca, the Strait of Georgia (sometimes called the Gulf of Georgia), Johnstone Strait and Queen Charlotte Strait, (bounded on the south by the international boundary between Canada and the United States of America, on the west by a line from Tatoosh Island lighthouse to Bonilla Point reference mark and on the north by a straight line drawn across Queen Charlotte Strait from Greeting Point on Nigel Island to McEwan Point on Branham Island) the property of the Queen in Right of the Province of British Columbia?

The Court found in favour of the Province but the decision has been appealed by the Federal Government. ${ }^{39}$

The marine areas referred to in the Reference, delimited by the British Columbia coastline and the closing lines are claimed by the province as its "inland marine zone". The closing lines are baselines from which the territorial sea of Canada is measured, and thus the waters have the status of inland waters, subject to the absolute sovereignty of the state. British Columbia contends that these waters are 'part' of the province and therefore British Columbia enjoys full jurisdiction for the purposes of mineral resource development.

Normally, the Territorial Sea is measured from the low-water mark, but in certain circumstances this is inappropriate. Where the coastline is deeply indented by bays, deltas, or fringed with islands, closing lines may be drawn to facilitate the delineation of offshore boundaries. ${ }^{40}$

The majority of the Court of Appeal of British Columbia held that the Supreme Court of Canada in the Offshore Mineral Rights Reference did not address itself to the question of the status of such inland waters, and that the status of the marine areas in question are not subject to the decision in that case. The Federal Government now seeks to close this gap which has appeared in what had seemed to be a settled juridical picture.

\section{THE MEMORANDUM OF UNDERSTANDING}

In 1977, Nova Scotia, Prince Edward Island, and New Brunswick signed a Memorandum of Understanding which was to form the basis of an Agreement concerning the management of offshore mineral resources. The Memorandum was designed to enable offshore exploration and development to proceed and embodied a settlement of the jurisdictional issue by providing for joint administration and revenue sharing. The legal and historical claims of the parties were to be ignored, as they were to be disregarded in the Canada-Nova Scotia Agreement of 1982. But unlike the later agreement, the decision-making process laid down by the Memorandum would have made it impossible for either the provincial "side" or the Federal government to have its way in the absence of agreement.

The Memorandum would have provided for the establishment of a Board composed of three Federal members, and one from each of the participating provinces. The offshore was to be divided into two areas. The first, landward of a line at least 5 kilometres from the low-water mark was to be administered by the adjacent province, or the Board, should that province so decide. Seaward of the line, to the edge of the shelf, was subject to the Board's jurisdiction.

39. The case was heard before the Supreme Court of Canada in October, 1982. The decision of the Court had not been handed down at this writing.

40. See the Anglo-Norwegian Fisheries Case (1951) I.C.J. Reports 116; Convention on the Territorial Sea and Contiguous Zone, Art. 4; Draft Convention on the Law of the Sea, Art. 7. 
The revenue from the areas was to be divided as follows. Canada was to receive 25 per cent of the revenues from the area seaward from the demarcation line. The provinces were to divide the remaining 75 per cent of the revenues accruing from production in this area according to their territorial jurisdiction as specified by agreed boundaries, and further subject to the provisions of a regional revenue sharing pool which was to have been established by the Agreement. Nova Scotia was to get 100 per cent of the revenues derived from Sable Island and the surrounding marine area.

The accord evidenced by the Memorandum was clearly one of principle only. Much would have remained to be specified in the proposed Agreement. This is the first of three such 'political solutions' to the offshore jurisdictional dispute, the others being the Canada-Nova Scotia Agreement, and Newfoundland's January, 1982, proposals for joint management and revenue sharing, both of which are discussed below. Some sort of political solution has several advantages; it removes offshore operators from the political arena, an arena in which they find themselves, unwillingly, at present ${ }^{41}$. It would also be a more effective demonstration of co-operative federalism than other recent forays in this sphere.

\section{THE FEDERAL POSITION - THE CANADA OIL AND GAS ACT}

The Canada Oil and Gas Act ${ }^{42}$ was proclaimed in March, 1982, following the conclusion of the Canada-Nova Scotia Agreement. The measure has generated, and continues to generate, a wealth of discussion and argument.

In the present context, the act may be seen not only as the latest indication of the Federal position on offshore jurisdiction, but a firm response to provincial claims. It also provided, for the first time, a firm legislative base for Federal oil and gas licences in the offshore.

The licensing regimes promulgated by the Canada Oil and Gas Land Regulations $\mathrm{s}^{43}$ of 1961 and 1977 were applied to the continental shelf, thereby extending the definition of Canada Lands. It is uncertain whether there was any statutory authority for this; the Regulations were issued pursuant to the Territorial Lands Act ${ }^{44}$ and the Public Lands Grants Act; ${ }^{45}$ since neither enactment contains a provision to the contrary, the usual presumption against extra-territorial (i.e., continental shelf) application must apply.

The ill-fated Bill C-20 would have extended the definition of "Canada Lands" to cover the shelf, incorporating the relevant passage of the Convention on the Continental Shelf of 1958, which Canada ratified in 1970:

41. Offshore operators in the Beaufort sea may find themselves in a difficult position if the government of the Northwest Territories attempts to levy taxes on artificial islands. It is unlikely that the Federal government would recognise the competence of the territorial government in this regard. But compliance or defiance would place the Operator in an invidious position of opposition to one or other government, while an Operator surely wishes to remain on good terms with both. One might also remark that governments should not settle jurisdictional lego-political problems through third parties in this way.

42. S.C. $1980-81-82$, c. 81 .

43. SOR/61-253, as am.; consolidated in C.R.C. 1978, c. 15.

44. R.S.C. 1970 , c. T-6.

45. R.S.C. 1970 , c. P.29. 
.. those submarine areas adjacent to the coast of Canada to a water depth of two hundred metres or beyond that limit to where the depth of superjacent waters admits of the exploitation of the natural resources of the seabed and subsoil thereof.

Bill C $-48^{46}$ reflects the development of international law in the interim, and provides a definition clearly based on the formulation incorporated into the Draft Convention on the Law of the Sea produced by the Third United Nations Conference on the Law of the Sea in $1981 ;^{47}$

... those submarine areas, not within a province, adjacent to the coast of Canada and extending throughout the natural prolongation of the land territory of Canada to the outer edge of the continental margin or to a distance of 200 nautical miles from the baselines from which the breadth of the Territorial Seas of Canada is measured, whichever is the greater. ${ }^{4}$

The Canada Oil and Gas Act applies to all Canada Lands (s.5(1)), and is intended to be binding on Her Majesty in Right of Canada or a province (s.5(4)). The Act does not contain an express vesting clause in favor of the Federal Crown, thus enabling a province to adopt the Act (albeit accepting Federal management of the offshore) without compromising its claim to exercise offshore jurisdiction.

\section{THE PROVINCIAL POSITION}

\section{A. Nova Scotia - 1982}

Nova Scotia withdrew from the Memorandum of Understanding when Premier Buchanan's Conservative government came to power, and reinstated the province's claim to exclusive rights over the mineral resources of the adjacent offshore. This claim was restated in section 7 of the Act Respecting Petroleum Resources, ${ }^{49}$ which was introduced in the provincial Legislature in 1980, and approved in 1981. Later in 1981, negotiations between the Federal and Newfoundland governments recommenced. In a less intense glow of publicity, negotiations between Ottawa and Nova Scotia also resumed, and the proclamation of the Petroleum Resources Act was delayed pending their outcome. These discussions bore fruit in the Canada-Nova Scotia Agreement of March 1982.

\section{The Canada-Nova Scotia Agreement - March 1982}

The Federal Liberal government which came to power in 1980 repudiated its predecessor's intention to recognize provincial jurisdiction in the offshore. Although exclusive Federal control was claimed, the Federal government offered co-operation and revenue sharing agreements with the provinces. The first such agreement was concluded with Nova Scotia in March, 1982. Whereas the B.C. Offshore Mineral Rights Reference ${ }^{50}$ recognized undisputed Federal jurisdiction over offshore resources and the Memorandum of Understanding left the issue unresolved by mutual consent, this agreement with Nova Scotia gave the Federal government, through the Canada Oil and Gas Act, exclusive jurisdiction over the resources in the offshore region subject to the terms of the Agreement with respect to decisions regarding development and revenue sharing. This was made plain by Nova Scotia's agreement to adopt the federal Act which

46. Now the Canada Oil and Gas Act, supra n. 40.

47. United Nations Doc. A/CONF. 62 WP 10/Rev. 3, August 1980, Article 76 (reprinted in (1980) 19 I.L.M. 1129).

48. Supra n. 40, s. 2(1).

49. S.N.S. 1980, c. 12.

50. Supra n. 13. 
claims exclusive licensing jurisdiction in respect of adjacent submarine areas (but not Sable Island). The inter-provincial offshore boundaries drawn up for the Memorandum of Understanding are employed to show the geographical extent of the Scotian shelf; the boundary with Newfoundland was never sanctioned by the latter. Similarly, the southern part of the Scotian shelf is delimited without regard to the outcome of the boundary dispute with the United States in the Gulf of Maine, which is to be settled by the International Court of Justice. The dispute with France concerning the offshore boundary between Canada and St. Pierre and Miquelon is ignored in a similar manner.

This offshore region is to be developed under the supervision of the Federal Minister of Energy, Mines and Resources, who will receive recommendations on offshore development and licensing from an appointed Board, which is to be comprised of three Federal members and two Nova Scotia members. The Minister is empowered, if he does not approve of a Board decision, to substitute his own, but before such a substituted decision is final the province has the right to delay implementation and make a plea for him to do otherwise. The Agreement clearly gives the Federal government the ultimate authority in matters such as pace of development. The advantage to Nova Scotia is in the terms of revenue sharing.

The revenue sharing provisions are wide-ranging. The province of Nova Scotia is to receive a percentage of Canada's 25 per cent share of interest as determined by the Canada Oil and Gas Act, 50 per cent of the Crown share in natural gas reserves, and 25 per cent of the Crown share in oil reserves.

The province is also entitled to receive oil and gas produced from the Scotian shelf sufficient to cover its domestic needs both present and future. The province will also receive 100 per cent of the following revenues from production until the status of a "have" province is attained, in which event Nova Scotia's share of the revenues will be gradually diverted into the Federal revenue sharing channels:

(i) proceeds of the basic royalty as specified in the Canada Oil and Gas Act.

(ii) proceeds of the progressive incremental royalty as found in the same Act.

(iii) revenues equivalent to those which would be generated by the provincial corporate tax as in the Nova Scotia Income Tax Act.

(iv) revenues equivalent to those which would be generated by a Nova Scotia retail sales tax, if this tax were to be extended to include the offshore region.

(v) any bonus payment.

(vi) any proceeds from rentals and licence fees to the extent that the instruments generate revenue in excess of the administrative costs pertinent to the offshore region.

As has been mentioned, the agreement calls for the Nova Scotia government to adopt the Canada Oil and Gas Act.

The agreement appears to be consistent with the juridical position on the west coast in that the Federal government retains ultimate jurisdiction over and management of offshore resources. There is an added advantage to Nova Scotia in that if the Federal government should ever negotiate a better agreement with any other province concerning offshore 
resource development, then Nova Scotia may substitute that agreement for the present one.

Clause 1 of the Agreement states: "This political settlement of the issues between the two governments has been reached without prejudice to and notwithstanding their respective legal positions". This statement reads almost as a caveat. A strict comparison with the Memorandum of Understanding might suggest that Nova Scotia, under this Agreement, has only token powers compared with those available to the "provincial side" under the former. Such considerations miss the point; administration and management of the offshore is an enormous and multi-faceted undertaking as the problems brought to light following the Ocean Ranger tragedy have indicated. The North Sea governments have assumed increasing control over all aspects of their licensees' offshore operations. They have implemented detailed regulatory codes covering matters which were previously dealt with by reference to the industry's own standards, and have instituted inspectorates to ensure that these codes are observed. Canadian governments have assumed similar responsibilities for the regulation and inspection of workplaces onshore; it is inconceivable that this responsibility will not be extended to offshore facilities.

This brings us back to the point that the term "jurisdiction" must be construed in its widest sense. Accordingly, Nova Scotia has elected not to attempt to duplicate the Federal government's regulatory and administrative functions as performed by the Department of Energy, Mines and Resources, and the Canada Oil and Gas Land Administration. This is surely a rational decision.

\section{B. Newfoundland}

By Order-in-Council of February 12, 1982, the Lieutenant-Governor of Newfoundland referred the following question to the Court of Appeal of the Supreme Court of the province -

Do the lands, mines, minerals, royalties or other rights, including the right to explore and exploit and the right to legislate, with respect to the mineral and other natural resources of the sea bed and sub-soil from the ordinary low-water mark of the Province of Newfoundland to the seaward limit of the continental shelf or any part thereof belong or otherwise appertain to the Province of Newfoundland?

Newfoundland's claim to exercise jurisdiction over the mineral resources of the adjacent continental shelf is based on the contention that the province entered Confederation already invested with these rights, and neither union with Canada nor any other subsequent act has divested her of them. There are two strands to the argument, both premised on the assumption that Newfoundland entered union with Canada in 1949 as a sovereign state, and that international law had operated so as to confer exclusive rights in offshore resources on her.

The first argument is that at the date of union with Canada, the doctrine of the continental shelf had become established in international customary law, and that as a sovereign state, Newfoundland exercised an exclusive resource jurisdiction over the mineral resources of the shelf which the terms of union did not disturb. In my view this argument is not a very strong one. Several states had indeed laid claim to offshore mineral resources by 1949, but the formation of a rule of international customary law requires more than a mere usage, or pattern of similar claims. It requires a constant practice accepted as law; therefore, there should be a 
solid bank of consistent state practice to support the assertion that a new rule of international customary law has been created.

Following the Truman Proclamation of 1945, Central and South American states laid claim to 200 nautical mile territorial seas, claiming that this was following the American lead. But there is clearly a substantial qualitative difference between a claim to exclusive mineral jurisdiction over the continental shelf and absolute sovereignty over a fixed offshore area, seabed, subsoil, superjacent water and airspace. At about the same time, the United Kingdom laid claim to areas of seabed around many of her colonies, including Jamaica, the Falkland Islands, and Trinidad, annexing the seabed and subsoil to the colony.

Sir Hersh Lauterpacht rightly detected the greatest enthusiasm for the nascent concept in 1950, and Professor Kunz was also right in 1956 to see in these claims to absolute ownership a threat to the freedom of the seas. It is submitted that when Newfoundland entered Confederation, there was no consistent practice accepted as law relating to offshore mineral jurisdiction. As Lord Asquith remarked in the course of his arbitral judgement in Petroleum Development Ltd. v. Sheikh of Abu Dhabi: ${ }^{11}$

... there are in this field so many ragged ends and unfilled blanks, so much that is merely tentative and exploratory, that in no form can the doctrine claim as yet to have assumed hitherto the hard lineaments or the definitive status of an established rule of international law.

The second argument is more complex. The International Court of Justice, in its decision on the North Sea Continental Shelf Cases, ${ }^{52}$ reviewed the development of the international law of the continental shelf and the nature of the coastal states' rights over the mineral resources thereof. The Court remarked that there could be no doubt that the fundamental rationale of the doctrine was that states exercised an exclusive offshore mineral resource jurisdiction ipso facto and $a b$ initio, by virtue of the sovereignty over the landmass. This was therefore an inherent right.

In the Newfoundland argument, this is interpreted as supporting the claim to offshore jurisdiction. If the Court was holding that offshore jurisdiction vested in all states, regardless not only of the absence of a specific claim, or knowledge of the existence of the resources, then the rights must have attached to Newfoundland when she was a sovereign state. It is central to the Newfoundland position that there was no divestiture of rights in favour of Canada on the date of Union, and therefore the province is entitled to exercise this right within the constitutional framework of Confederation.

It is open to doubt just how far the Supreme Court of Canada will be impressed by such an argument. The B.C. Offshore Minerals Reference $e^{53}$ showed the Court rather insensitive to the international-municipal legal nexus.

The question referred by the Government of Newfoundland is more comprehensive than that posed in the B.C. Reference. Here, the Court is required to consider submarine areas in three distinct juridical areas: inland waters (i.e., water landward of the baselines, for the text refers to areas seaward of the "ordinary low-water mark of Newfoundland"), the

51. [1951] I.L.R. 144.

52. (1969) I.C.J. Reports 3.

53. Supran. 13. 
Territorial Sea, and the Continental Shelf. Taken together, the three areas are, or will be dealt with by the Supreme Court of Canada in the Strait of Georgia and the B.C. Offshore Minerals references.

In addition, there is the vexed question of the "right to legislate". Although the ultimate determination of oil and gas rights in favour of the province in any part of submarine areas of the adjacent offshore must recognize the vesting of licensing and other associated rights, the existing division of legislative power effected by the B.N.A. Act will remain. The point was well made by the decision of the Federal Court in the Seafarers' International Union (S.I.U.) case.

Even though the question of offshore jurisdiction has been referred to the courts, the parties have continued to negotiate in an attempt to settle the dispute. Since the basis for discussion is joint management without regard to the question of legal ownership or jurisdiction (as with the Nova Scotia Agreement), judicial pronouncements would perhaps be politically embarassing in that equality at the bargaining table would be impossible.

Newfoundland's present position was revealed on January 25, $1982^{54}$. The province proposes that revenues should be apportioned between the two governments in order to permit Newfoundland to achieve and maintain a level of fiscal maturity and independence comparable with that of Ontario, Alberta and British Columbia. Public services and tax burdens should be comparable with those obtained in these provinces. The government portion should be divided between the parties so as to achieve this goal, and once achieved, the Federal portion would increase accordingly.

Management would be entrusted to a joint agency, operating under criteria and regulations agreed to by the parties, and administered by an executive body composed of three Federal and three provincial appointees, and a jointly appointed chairman. Each government would retain a measure of exclusive control in certain situations, but would be required to justify unilateral decisions in the context of the joint criteria.

Newfoundland has dismissed the Canada-Nova Scotia Agreement on the grounds that it provides for ultimate federal control, and that the revenue sharing provisions are inadequate. It should be remembered that Nova Scotia retains the right to substitute a subsequent agreement for the March, 1982, accord if it feels that the provincial position in such an agreement is more favourable than its own. If the federal government and Newfoundland reach an accord on the basis of the latter's proposals, it may well be that the Nova Scotia Agreement will have served as a starting point for the ultimate settlement of the jurisdictional dispute while permitting development of the Scotian shelf to proceed in the interim. However, the Newfoundland proposals can only succeed if the two sides display greater political will than has been shown hitherto in filling out the myriad blanks and working out the 'agreements to agree' scattered throughout them.

\section{THE IMPACT OF THE S.I.U. CASE}

The decision of the Federal Court of Appeal in Seafarers' International

54. The Proposals are reproduced together with the text of the Canada-Nova Scotia Offshore Resources Agreement, and a critique thereon, in "An Analysis of The Impact of a Nova Scotia Type Offshore Agreement on Newfoundland", Newfoundland Petroleum Directorate, August 1982. 
Union of Canada v. Crosbie Offshore Services Ltd. ${ }^{55}$ was rendered on March 5, 1982. The case arose out of a refusal by the Canada Labour Relations Board (CLRB) to take jurisdiction and hear S.I.U.'s application for certification as bargaining agent for some workers employed by the Respondent, Crosbie, on offshore supply vessels. The Newfoundland Labour Relations Board had entertained an application from other unions concerning certification in respect of the same workers which was still being decided when the SIU applied to the CLRB. On this basis, the CLRB decided that its jurisdiction was pre-empted.

When the case came before the Federal Court, the Attorney General for Canada intervened on behalf of the Applicant, submitting that the issue should be decided in favour of the CLRB because Canada, and not the province, had jurisdiction over all aspects of offshore operations, including oil and gas exploration and development. The Attorney General for Newfoundland intervened on the side of the Respondent, submitting that the operations in question were local, and hence the Newfoundland Board alone had jurisdiction and that jurisdiction over offshore minerals was irrelevant in any case. The Attorney General for Canada, taking a leaf out of the Newfoundland book, perhaps, filed some nineteen volumes of historical material in support of the Federal position; parts of the factum submitted by him are in effect a detailed survey of the evolution of the doctrine of the continental shelf in international law.

The Federal Court decided unanimously that the CLRB decision had been incorrect but declined to discuss the question of offshore resource jurisdiction, holding that this was irrelevant and unnecessary for determination of the issue. It was held that the activities of Crosbie Offshore Services Ltd.., although providing a diverse range of marine services, were nonetheless subject to the Federal legislative jurisdiction with respect to shipping.

Although the Federal strategy of attempting to broaden the case so that it became, in effect, a "dry run" for a jurisdiction reference to the Supreme Court failed, the decision again shows that the question of "offshore jurisdiction" is very much wider than a dispute over resources.

\section{THE FEDERAL REFERENCE TO THE SUPREME COURT OF CANADA}

The Federal government announced on May 19, 1982, that it intended to refer the question of jurisdiction over the Hibernia oil field to the Supreme Court of Canada. The Federal reference, by limiting itself to the question of jurisdiction over submarine minerals on the continental shelf, would leave aside questions concerning submarine mineral resource jurisdiction in inland waters and the Territorial Sea. It also focuses attention on the stalemate off the coast of Newfoundland because the area defined in the reference includes part of the largest discovery of hydrocarbons in the Canadian offshore, the development of which has been stalled, largely because of the jurisdictional dispute.

However, it appears that the Supreme Court of Canada will not hear the Federal reference until after the Newfoundland Court has pronounced on the provincial case. In the absence of a political agreement, that case will eventually come before the Supreme Court of Canada, thereby ensuring

55. Supran. 8. 
that the Court will consider the matter of jurisdiction in the Newfoundland offshore seaward of the low-water mark to the edge of the continental margin.

\section{FUTURE PROSPECTS}

The preceding sections of this paper have merely charted the course of the Federal-provincial dispute concerning offshore mineral resources. Canada is now in her third decade of offshore oil exploration. The North Sea countries have, within the same time frame, built up an offshore oil and gas industry from nothing to a point where the United Kingdom and Norway must be counted as major producers of petroleum from the offshore. Major parts of the Canadian legal regime for the offshore are still bedevilled by a number of doubts and uncertainties. While it is clearly naive to expect complete certainty in the law at all times, it is possible to establish a stable legal regime which at least attempts to settle ambiguities and fill lacunae in the law when their presence becomes all too obvious.

It seems clear that the Canada-Nova Scotia Agreement is largely the product of the mutual political will of the two parties to ensure that offshore hydrocarbon exploration is intensified, and to get production under way in the near future. It remains to be seen whether the parties can maintain this momentum to resolve any conflicts of opinion which may arise from the implementation of the accord. Whether a political solution can be reached between Ottawa and the other coastal provinces remains to be seen. The government of British Columbia has stated that it does not regard the decision of the Supreme Court of Canada in the B.C. Offshore Minerals case as finally settling the question, and Premier Peckford has also indicated that an adverse ruling in the courts will not deter him from securing a measure of control over the development of the submarine natural resources adjacent to Newfoundland.

Apart from these issues, there are a large number of other questions yet to be resolved. On the international plane, Canada has yet to determine any of her four offshore boundaries with the United States, or with France in respect of St. Pierre and Miquelon. It now appears that the government of Canada is claiming that the waters of the islands of the Canadian Arctic Archipelago are inland waters, thereby attempting to resolve at least one ambiguity in the area. However, at the same time, the government of the Northwest Territories appears to consider that it has the right to tax artificial islands in the Beaufort Sea as if they were "land". The papers by Professor de Mestral and Professor Mendes which appeár elsewhere in this volume also underline serious deficiencies in the Canadian legal regime applicable to the offshore. One can easily add other deficiencies to this list. For example, it remains to be seen how the Canada Oil and Gas Lands Administration will proceed with the implementation of the Canada Oil and Gas Act. Furthermore, the extent to which COGLA will assume other responsibilities with respect to offshore operations which might be considered as the province of other government departments, such as the Department of the Environment (with respect to the environmental provisions of the Act) and Transport Canada (with respect to supply vessels in the offshore, and offshore facilities), is yet to be seen.

While the National Energy Program addresses certain aspects of natural resource production, a more comprehensive policy addressing other 
operational rather than conceptual issues is also required. It is in this context that a political solution to offshore jurisdictions should be sought, not as an end in itself, but only as part of a larger process of establishing a settled legal administrative regime for the proper exploration for and exploitation of the mineral resources of Canada's offshore. 